\title{
Peningkatan Keamanan melalui Penerapan e-Linmas Desa Rimba Makmur
}

\author{
Nurjayadi $^{1}$, Herwin $^{2 *}$, Khusaeri Andesa ${ }^{3}$, Torkis Nasution ${ }^{4}$ \\ Sekolah Tinggi Manajemen Informatika dan Komputer Amik Riau \\ email: nurjayadi@sar.ac.id
}

\begin{abstract}
The Rimba Makmur Linmas group is engaged in community empowerment. The problem is the wide village area, information technology implementation, low awareness. This community service aims to increase the role of Linmas in limited human resources to increase security through the implementation of e-Linmas. The solution is to increase community participation in maintaining security, determine entry and exit routes from the village, use incoming and outgoing detection tools, install e-Linmas applications, provide training on application use, application implementation, assistance in application use. In the field of low awareness, efforts have been made to increase public awareness in maintaining village security. Efforts made are the use of sirens, the use of smartphone devices. Contributions and benefits obtained by the target audience is the use of the results of the application of appropriate technology for community service programs as a solution to the development of information technology in partnership with the Rimba Makmur Village Community Community Group. The increase in participants' knowledge is measured through the implementation of pre-test and post-test. The results of the pre-test were $12 \%$ correct answers, $84 \%$ wrong answers, and $4 \%$ doubtful answers. , after carrying out training and mentoring then a post-test was carried out, the results achieved an increase in correctness of 67\%, a decrease in wrong answers by $29.5 \%$ and doubting by $5 \%$.
\end{abstract}

Keywords: e-Linmas, alarm, security, ICT

\begin{abstract}
Abstrak
Kelompok Linmas Rimba Makmur bergerak dalam bidang pemberdayaan masyarakatan. Permasalahannya adalah Wilayah Desa Luas, Implementasi Teknologi Inforamsi, Kesadaran Rendah. Pengabdian kepada masyarakat ini bertujuan meningkatkan peran Linmas dalam keterbatasan sumber daya manusia untuk meningkatkan ekamanan melalui penerapan e-Linmas. Solusi yang dilakukan adalah meningkatkan peran serta masyarakat dalam menjaga keamanan, menetapkan jalankeluar masuk dan masuk dari desa, menggunakan alat deteksi yang masuk dan keluar, instalasi aplikasi e-Linmas, memberikan pelatihan penggunaan aplikasi, implementasi aplikasi, pendampingan penggunaan aplikasi. Dalam bidang kesadaran rendah upaya yang dilakukan meningkatkan kesadaran masyarakat dalam menjaga keamanan desa. Upaya yang dilakukan adalah penggunaan sirene, pemanfaatan perangkat smartphone. Kontribusi dan manfaat yang diperoleh khalayak sasaran adalah penggunaan hasil penerapan teknologi tepat guna program pengabdian kepada masyarakat sebagai solusi dari pengembangan teknologi informasi bermitra dengan Kelompok Linmas Desa Rimba Makmur. Peningkatkan pengetahuan peserta di ukur melalui pelaksaan pre-test dan pos-test. Hasil pre-test adalah jawaban benar $12 \%$, salah $84 \%$, dan ragu-ragu 4\%., setelah melaksanakan pelatihan dan pendampingan kemudian dilakukan post-test, capaian hasil terjadi peningkatan benar $67 \%$, penurunan salah jawaban $29,5 \%$ dan ragu-ragu $5 \%$.
\end{abstract}

Kata Kunci: e-Linmas, sirene, keamanan, TIK 


\section{PENDAHULUAN}

Satuan Perlindungan Masyarakat dibentuk berdasarkan pada Peraturan Menteri Dalam Negeri Republik Indonesia Nomor 26 Tahun 2020 Tentang Penyelenggaraan Ketertiban Umum dan Ketenteraman Masyarakat Serta Pelindungan Masyarakat. Pada Linmas mengacu pada Pasal 1 ayat 8: Pelindungan Masyarakat yang selanjutnya disebut Linmas adalah segenap upaya dan kegiatan yang dilakukan dalam rangka melindungi masyarakat dari gangguan yang diakibatkan oleh bencana serta upaya untuk melaksanakan tugas membantu penanganan bencana guna mengurangi dan memperkecil akibat bencana, membantu memelihara keamanan, ketenteraman dan ketertiban masyarakat, membantu kegiatan sosial kemasyarakatan, membantu memelihara ketenteraman dan ketertiban pada saat pemilihan kepala desa, pemilihan kepala daerah, dan pemilihan umum, serta membantu upaya pertahanan negara. Cakupan kegiatan di paparkan pada Pasal 2 ayat 4: Penyelenggaraan Ketertiban Umum dan Ketenteraman Masyarakat sebagaimana dimaksud pada ayat (1) dan ayat (2), meliputi kegiatan: a. deteksi dan cegah dini; b. pembinaan dan penyuluhan; c. patroli; d. pengamanan; e. pengawalan; f. penertiban; dan g. penanganan unjuk rasa dan kerusuhan massa.

Kondisi riil menunjukkan bahwa Satlinmas mengalami kendala dalam menjalankan fungsi dengan sebaikbaiknya [1]. Permasalahan utama adalah luas wilayah pemukiman, jumlah penduduk yang relatif banyak, beserta akses jalan yang dilalui oleh kendaraan roda dua. Pada saat ini akses jalan roda empat, terdapat 2 jalan yang dapat digunakan, satu jalan dilengkapi dengan pos penjagaan dan palang yang dapat di buka tutup. Upaya menjaga keamanan dan ketertiban dibutuhkan penambahan anggota, peran serta masyarakat, maupun pemanfaatan teknologi yang turut mendukung antisipasi potensi gangguan ketertiban dan keamanan. Ketua Satlinmas, Bapak Rimin MW, menyampaikan bahwa permasalahan yang di alami pada saat ini adalah luasnya wilayah dan jumlah penduduk yang relatif banyak [2]. Dalam pertemuan tersebut, Ketua Satlinmas berharap kepada TIM PPDM STMIK Amik Riau agar dapat memberikan uapaya pemecahan masalah berupa pemanfaatan teknologi informasi untuk meningkatkan ketertiban dan keamanan serta mengusahakan dengan bantuan teknologi agar masyarakat dapat berperan serta dan proaktif dalam mencegah potensi gangguan ketertiban dan keamanan [3]. Identifikasi permasalahan yang dikemukakan oleh Ketua Satlinmas adalah:

1. Kurangnya tenaga yang tersedia dibandingkan dengan luasan wilayah pemukimanan penduduk.

2. Kurangnya kesadaran masyarakat tentang arti penting menjaga ketertiban dan keamanan lingkunga.

3. Banyaknya jumlah masyarakat yang harus di jaga dalam keadaan tertntu tidak dapat di antisipasi potensi gangguan

4. Kurangnya peran teknologi dalam menjaga dan meningkatkan ketertiban dan keamanan secara berkelanjutan.

5. Kurangnya kepedulian dan kepekaan terhadap persoalan-persoalan kemasyarakatan yang berkembang.

6. Masih kurang dan belum optimalnya personil Linmas yang terlibat dalam menjaga keamanan dan ketertiban masyarakat

Mitra Kelompok Linmas Rimba Makmur bergerak dalam bidang pemberdayaan masyarakatan. Permasalahannya adalah Wilayah Desa Luas, Implementasi Teknologi Inforamsi, Kesadaran Rendah [4]. Bidang wilayah desa, yaitu Bagaimana meningkatkan peran Linmas wilayah luas dengan keterbatasan jumlah sumber daya manusia 
Desa Rimba Makmur. Solusinya adalah: (1) meningkatkan peran serta masyarakat dalam menjaga keamanan [4]; (2) Menetapkan jalankeluar masuk dan masuk dari desa; (3) Menggunakan alat deteksi yang masuk dan keluar. Bidang implementasi teknologi informasi yaitu Bagaimana meningkatkan peran Linmas menggunakan teknologi informasi. Solusi adalah (1) instalasi aplikasi e-Siskamling; (2) memberikan pelatihan penggunaan aplikasi; (2) implementasi aplikasi; (3) pendampingan penggunaan aplikasi. Bidang kesadaran rendah, yaitu Bagaimana meningkatkan kesadaran masyarakat dalam menjaga keamanan desa. Solusi adalah: (1) Penggunaan Sirene; (2) Pemanfaatan perangkat smartphone.

\section{METODE PENGABDIAN}

\section{Metode Pendekatan Kegiatan}

Untuk mencapai tujuannya kegiatan PPDM e-Desa Rimba Makmur akan dilakukan melalui beberapa pendekatan, antara lain:

1. Model Participatory Rural Appraisal (PRA) yang menekankan keterlibatan masyarakat dalam keseluruhan kegiatan mulai dari perencanaan, pelaksanaan dan evaluasi program kegiatan.

2. Model Participatory Technology Development yang memanfaatkan teknologi tepat guna yang berbasis pada ilmu pengetahuan dan kearifan budaya lokal.

3. Model Community development yaitu pendekatan yang melibatkan masyarakat secara langsung sebagai subyek dan obyek pelaksanaan kegiatan pengabdian kepada masyarakat.

4. Persuasif yaitu pendekatan yang bersifat himbauan dan dukungan tanpa unsur paksaan bagi masyarakat untuk berperan aktif dalam kegiatan ini.
5. Edukatif yaitu pendekatan sosialisasi, pelatihan dan pendampingan sebagai sarana transfer ilmu pengetahuan dan pendidikan untuk pemberdayaan masyarakat [5].

\section{Teknis Pelaksanaan Kegiatan}

Secara teknis, pelaksanaan kegiatan PPDM e-Desa Rimba Makmur adalah sebagai berikut:

1. Persiapan

Pada tahap persiapan ini dilakukan untuk menginventarisasi adanya perubahan kondisi masyarakat khususnya Kelompok Linmas Desa Rimba Makmur sehingga desain kegiatan yang telah dilakukan dapat memberikan solusi bagi permasalahan mitra. Selain itu di tahap awal ini juga akan dilakukan sosialisasi program secara lebih luas kepada masyarakat, pegawai Linmas Desa Rimba Makmur.

2. Pelaksanaan kegiatan.

Pelaksanaan kegiatan meliputi kegiatan penguatan penguasaan perangkat keras dan perangkat lunak melalui implementasi teknologi, memberikan pelatihan secara bertahap dan berkelanjutan, memberikan pendampingan untuk menjalankan program yang telah di sepakati bersama [6]. Kegiatan penguatan tata kelola organisasi dan kegiatan pengembangan SDM Kelompok Linmas Desa Rimba Makmur. Pelatihan, workshop dan pendampingan akan dilakukan untuk meningkatkan pengetahuan dan kemampuan sehingga usaha pelayanan yang dikelola dapat berkembang dan berkelanjutan. Pendampingan terus dilakukan pada kelompok Linmas, untuk bersiap mencapai smart economy. Kelompok Linmas menerapkan sistem pemasaran berbasis teknologi informasi dengan 
memanfaatkan perangkat mobile berbasis cloud computing.

Evaluasi dan monitoring kegiatan. Evaluasi dan monitoring kegiatan dilakukan secara periodik dengan melibatkan anggota pelaksana dan tokoh masyarakat desa dan bapak kepala Desa Rimba Makmur. Setiap periode evaluasi dilaksanakan secara keseluruhan untuk mengetahui derajat keberhasilan kegiatan berdasarkan target yang telah ditetapkan. Hasil evaluasi pelaksanaan pertama akan dijadikan dasar untuk pelaksanaan selanjutnya dan seterusnya.

\section{HASIL DAN PEMBAHASAN}

Pelaksanaan pengabdian masyarakat ini dirancang sesuai dengan kebutuhan mitra berdasarkan hasil survey kebutuhan yang telah dilaksanakan sebelumnya. Analisa kebutuhan dijabarkan dalam kegiatan sosialisasi dan pelatihan yang berlangsung selama 1 semester dan membutuhkan adanya pendampingan. Pendampingan diperlukan karena nelayan sulit untuk menjalankan program karena keterbatasan pengetahuan(Yenida \& Sumiarti, 2015), rendahnya tingkat pendidikan (Hamdani \& Wulandari, 2016), pendampingan selama 3 kali untuk mengoptimalkan hasil dan tujuan pengabdian masyarakat dapat tercapai. Kegiatan pengabdian masyarakat dilaksanakan di Desa Rimba Makmur, Kecamatan Tapung, Kabupaten Kampar, Riau diikuti oleh 20 peserta dengan menggunakan protokol kesehatan. Panitia dan peserta diwajibkan untuk melakukan cuci tangan sebelum memasuki tempat kegiatan. Selanjutnya peserta melakukan registrasi untuk memperlancar pelaksanaan kegiatan sehingga peserta dapat dengan mudah untuk didata dan didampingi pada saat pelaksanaan sosialisasi, pelatihan, dan pendampingan.

Kegiatan pengabdian ini didahului dengan persiapan pelaksanaan kegiatan, yaitu penyebaran formulir peserta untuk mitra Linmas, dan kegiatan sosialisasi. Kegiatan sosialisasi bertujuan untuk memberi informasi tentang agenda kegiatan dan tujuan pelaksanaan kegiatan serta mencari kesepakatan tentang jadwal pelaksanaan dan materi yang disajikan. Setelah dilaksanakan sosialisasi yang dihadiri oleh beberapa aparatur desa diperoleh peserta sebanyak 20 (Dua puluh) orang. Jadwal pelatihan, yaitu pada tanggal 2 Januari - 30 Oktober 2021. Kegiatan selanjutnya adalah persiapan kelengkapan kegiatan yang meliputi hal-hal sebagai berikut:

1. Mempersiapkan tempat pelaksanaan pelatihan, yaitu memakai ruang Aula Pertemuan Kantor Desa Rimba Makmur.

2. Mempersiapkan komputer dan perangkat smartphone milik desa dan perangkat yang dimiliki masingmasing perserta beserta peralatan komputer sebagai peralatan utama dalam pelatihan untuk menjamin ketersediaan sarana dan prasarana yang mendukung pelatihan aplikasi Linmas serta suasana yang kondusif.

3. Mempersiapkan software yang digunakan dalam pelatihan, yaitu perangkat Sistem Operasi Linux yang telah diinstal pada komputer remote server.

4. Mempersiapkan media presentasi, yaitu slide presentasi yang dibuat oleh trainer dan LCD.

5. Pembuatan modul yang digunakan dalam pelatihan. Modul tersebut dibuat oleh panitia pelaksana (trainer) dengan cakupan berupa materi-materi yang diberikan dalam pelatihan. Modul tersebut dibuat dalam bentuk tutorial, teori, dan latihan problem 
solving. Hal tersebut bertujuan untuk memudahkan peserta dalam memahami materi.

6. Mempersiapkan starter kit berupa $I D$ Card bagi peserta, notes, dan alat tulis untuk melancarkan proses pembelajaran saat pelatihan berlangsung.

Kegiatan dibuka oleh Kepala Desa dan Komandan Linmas, selanjutnya menyerahan plakat sebagai pembuka kegiatan Pengabdian ke Desa. Kegiatan yang bertempat di Aula Desa Rimba Makmur ini dihadiri oleh ketua dan anggota pelaksana kegiatan, para tim pendamping (mahasiswa STMIK Amik Riau), dan seluruh anggota Linmas yang menjadi peserta pelatihan. Pada kesempatan ini juga dilakukan penyerahan modul, perangkat sirene, serta melakukan latihan dan dipraktikkan dalam pelatihan (Gambar 1, 2, dan 3).

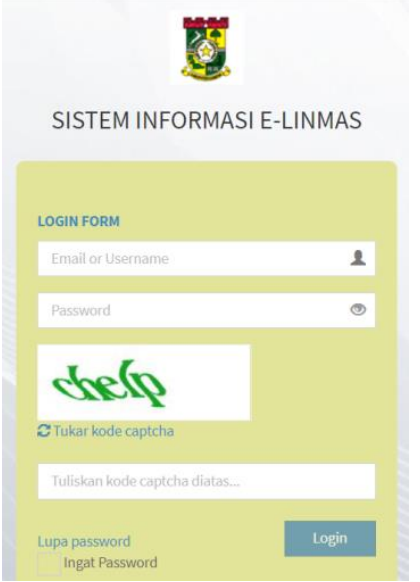

Gambar 1. Halaman Masuk ke dalam sistem e-Linmas

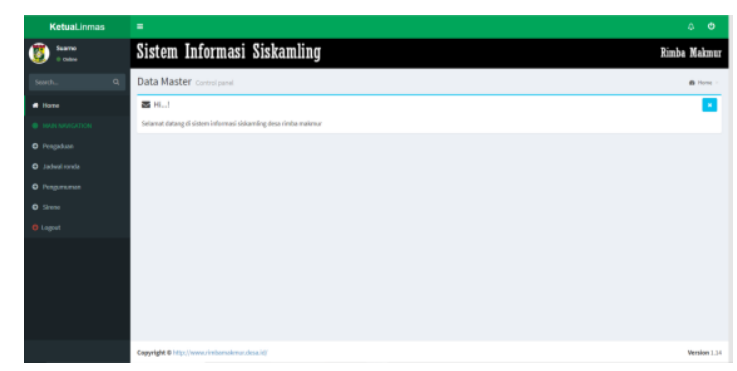

Gambar 2. Foto Pelaksanaan pelatihan doi: https://doi.org/10.37859/jpumri.v5i2.3110
Dalam kegiatan pelatihan dikenalkan server dan konfigurasi jaringan komputer yang masih belum dipahami secara mendalam oleh peserta dari institusi mitra. Pengenalan tersebut dilakukan dengan bantuan pemateri dan modul yang ada. Kegiatan kemudian dilanjutkan dengan instalasi perangkat lunak dan praktik langsung ke komputer dan smartphone. Berdasarkan pengalaman tim pelaksana yang juga pernah menjadi dosen pengampu mata kuliah pemrograman web dan jaringan komputer diketahui bahwa proses penggunaan aplikasi tanpa mencoba/praktik langsung akan sangat sulit diterima oleh peserta. Oleh karena itu, praktik langsung dengan komputer sangat diperlukan untuk memudahkan peserta dalam memahami materi.

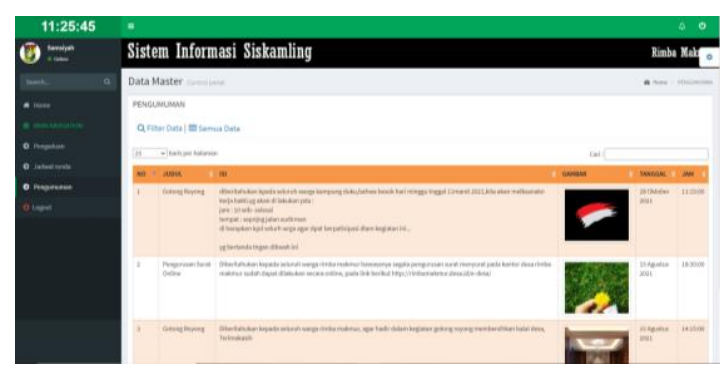

Gambar 3. Halaman Data Master

Pengumuman

Mengingat materi aplikasi Linmas yang sangat banyak dan dengan pertimbangan agar proses pelatihan dapat disampaikan secara maksimal, pembahasan kemudian dibagi menjadi tiga kali pertemuan. Pembagian materi pembahasan meliputi metode pelatihan, seperti pengajaran di kelas yang terdiri atas pemaparan teori, praktik, dan latihan soal. Latihan soal yang diberikan berasal dari studi kasus yang nyata terjadi di tatanan kehidupan masyarakat sebelumnya yang sesuai dengan topik materi yang disampaikan pada saat pertemuan tersebut. Lama setiap 
pertemuan adalah tujuh jam dan dilaksanakan pada hari yang tidak mengganggu aktivitas masyarakat khususnya peserta pelatihan.

Pertemuan pertama adalah agenda pretest yang bertujuan untuk mengukur kemampuan peserta, khususnya yang berkaitan dengan soal-soal mendasar pada aplikasi Linmas. Hasil dari pre-test dijadikan sebagai pembanding tingkat keberhasilan tim dalam memberi pelatihan kepada peserta. Selain itu, hasil tersebut juga digunakan untuk melihat peningkatan pemahaman peserta dadalam mengoperasi apliaksi Linmas jika dibandingkan dengan pre-test yang belum mendapatkan pelatihan satu kali pun. Dengan demikian, tes-tes selanjutnya, post-test (pertemuan terakhir) dijadikan sebagai evaluasi oleh tim pelaksana, yaitu dengan membandingkan hasil post-test dengan pre- test. Perbandingan tersebut dilakukan untuk melihat peningkatan hasil tes ketika dibandingkan dengan hasil post-test (pertemuan terakhir)

Pemantapan dilaksanakan untuk meningkatkan pemahaman dan kemampuan dasar dalam mengoperasi aplikasi Linmas dilakukan untuk setiap pemberian materi, dengan peserta 20 orang, diberikan 12 (dua belas) pertanyaan yang di anggap menjadi indikator utama keberhasilan capaian materi pelatihan. Pada saat pre-test, umumnya peserta menjawab soal tidak sesuai, digambarkan pada grafik yang berwarna merah, sebagian peserta ragu dalam memberikan jawaban.

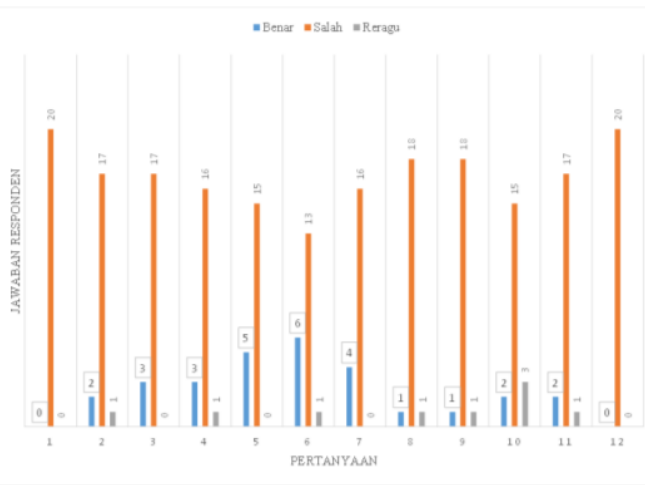

Gambar 4. Grafik yang menggambarkan pelaksanaan Pre-Test

Setelah mengikuti pelatihan, terjadi peningkatan kemampuan peserta, terjadi peningkatan walaupun tidak drastik. Hasil post-test di lihat pada gambar 2 .

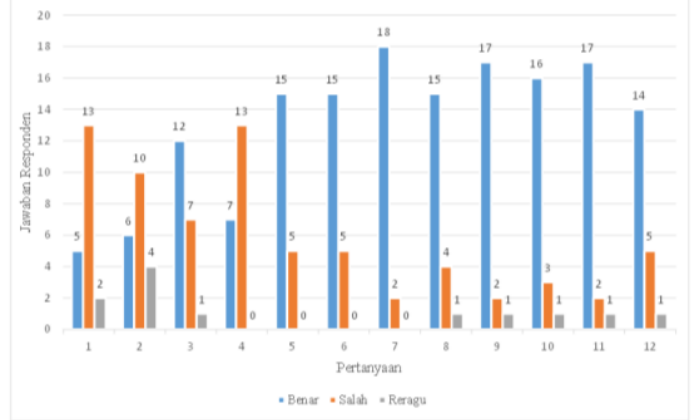

Gambar 5. Grafik yang menggambarkan pelaksanaan Post-Test

Setelah pelaksanaan workshop, berdampak terhadap peningkatan kemampuan peserta, hal ini dibuktikan dengan peningkatan kemampuan menjawab benar setelah workshop sebesar 34 jawaban (22\%). Kebalikan pada jawaban salah, terjadi penurunan sebesar 15 jawaban (15\%). Pada awal pelaksanaan workshop, peserta masih ragu-ragu dalam memberikan jawaban, hal ini terlihatpada jawaban yang ragu-ragu sebesar 21 jawaban, setelah pelatihan terjadi penurunan sebesar 19 jawban (90.48\%). Hasil Evaluasi terhadap kegiatan pelatihan ini dapat di lihat pada tabel 1 di bawah ini. 
Tabel 1. Hasil Evaluasi Pre-Test dan PostTest

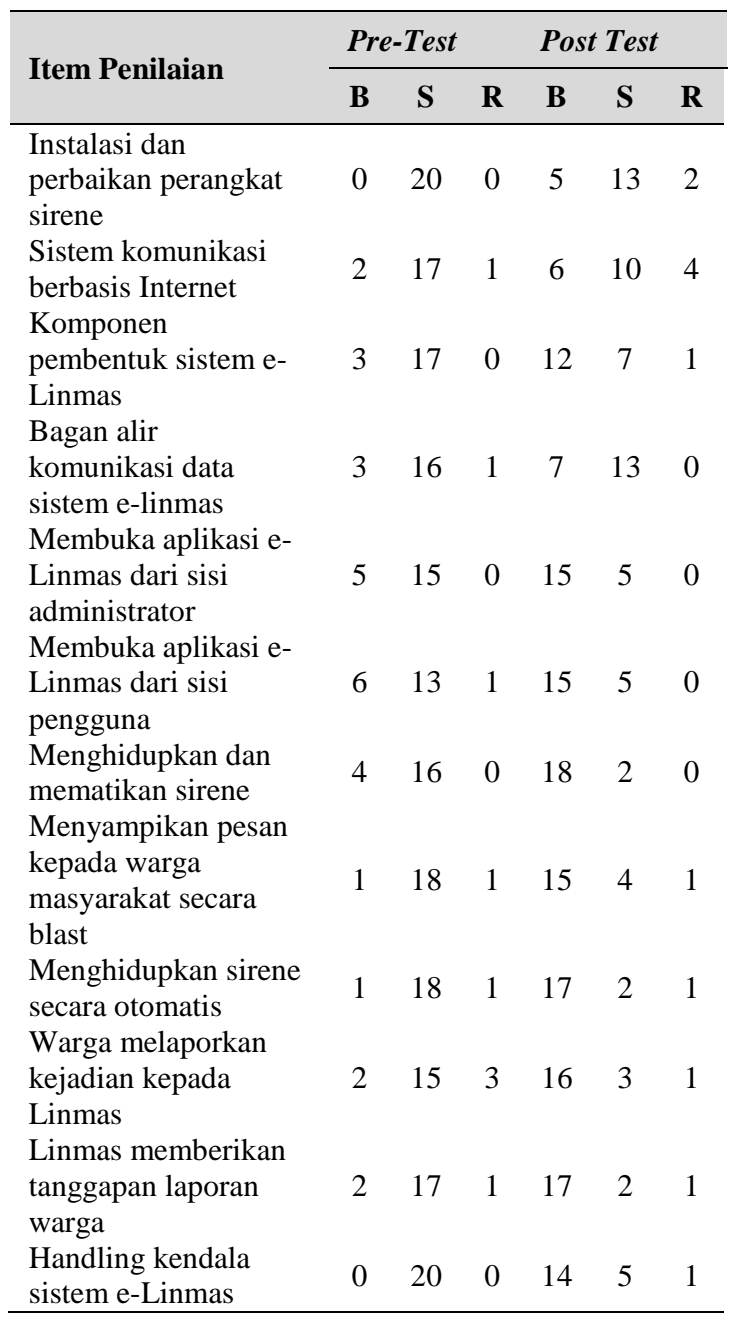

Secara umum peserta puas atas materi yang telah diberikan oleh tim STMIK Amik Riau, hal ini digambarkan pada dengan peserta yang Sangat Setuju sebesar 103, Setuju sebesar 104 peserta.

Tabel 2. Tingkat kepuasan peserta

\begin{tabular}{lcccc}
\hline $\begin{array}{l}\text { Butir-Butir } \\
\begin{array}{l}\text { Penilaian } \\
\text { (Feedback) }\end{array}\end{array}$ & STS & TS & S & SS \\
\hline $\begin{array}{l}\text { Program pengabdian } \\
\text { kepada masyarakat }\end{array}$ & 0 & 0 & 22 & 20 \\
$\begin{array}{l}\text { ini sudah sesuai } \\
\text { dengan tujuan } \\
\text { kegiatan itu sendiri. }\end{array}$ & & & & \\
\hline
\end{tabular}

\begin{tabular}{|c|c|c|c|c|}
\hline $\begin{array}{l}\text { Butir-Butir } \\
\text { Penilaian } \\
(\text { Feedback })\end{array}$ & STS & TS & $\mathbf{S}$ & SS \\
\hline $\begin{array}{l}\text { Program Pengabdian } \\
\text { kepada Masyarakat } \\
\text { ini sudah sesuai } \\
\text { dengan kebutuhan } \\
\text { masyarakat sasarnya. }\end{array}$ & 0 & 0 & 23 & 19 \\
\hline $\begin{array}{l}\text { Waktu pelaksanaan } \\
\text { program pengabdian } \\
\text { masyarakat ini relatif } \\
\text { telah mencukupi } \\
\text { sesuai kebutuhan. }\end{array}$ & 0 & 2 & 29 & 11 \\
\hline $\begin{array}{l}\text { Dosen dan } \\
\text { mahasiswa STMIK } \\
\text { Amik Riau bersikap } \\
\text { ramah, cepat dan } \\
\text { tanggap membantu } \\
\text { selama kegiatan. }\end{array}$ & 1 & 0 & 19 & 22 \\
\hline $\begin{array}{l}\text { Desa menerima dan } \\
\text { mengharapkan } \\
\text { program pengabdian } \\
\text { kepada masyarakat } \\
\text { STMIK Amik Riau } \\
\text { saat ini dan masa } \\
\text { yang akan datang. }\end{array}$ & 0 & 0 & 11 & 31 \\
\hline
\end{tabular}

Pada Gambar 6 diperlihatkan hasil Pre-Test dengan nilai 52,8\% dan Post-Test dengan nilai $72,6 \%$ yang dilakukan di Desa Rimba Makmur, Kecamatan Tapung, Kabupaten Kampar, Riau. Dari hasil tersebut diperoleh adanya peningkatan pemahaman dari peserta pelatihan pemrograman web sebesar 19,8\%, ditunjukkan pada hasil pelaksanaan pretest gambar 7. Pembinaan dilakukan setelah pelatihan dan prosesnya dilakukan secara fleksibel. Hal itu berarti bahwa proses pembinaan tidak terjadwal dan bisa dilakukan melalui berbagai sarana komunikasi, seperti via telepon, SMS, dan aplikasi media sosial. Pemateri memberi contact person kepada seluruh peserta sehingga jika peserta menemui kesulitan yang berkaitan dengan problem solving konfigurasi jaringan komputer setelah 
pelatihan, pemateri tetap dapat membantu memecahkan permasalahan tersebut. Penitikberatan kegiatan pembinaan ialah pada bantuan ketika menghadapi kesulitan dalam proses latihan soal LKS yang dilakukan peserta secara mandiri modul dan Penyerahan Sertifikat Peserta Pelatihan.

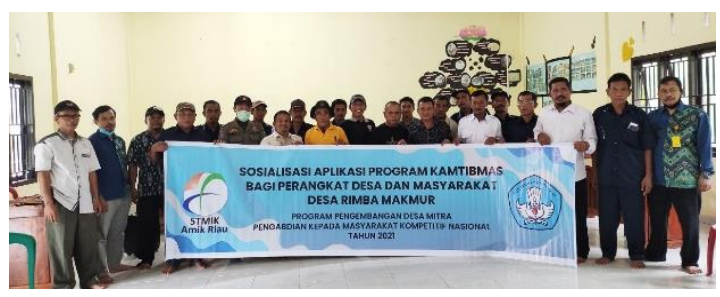

Gambar 8. Foto bersama dengan Kepala

Desa dan dan peserta pelatihan

Kegiatan penutupan diisi dengan ramah tamah dan penyampaian kesan serta saran dari peserta selama kegiatan pengabdian berlangsung untuk perbaikan kegiatan berikutnya. Panitia Pelaksana dan Pemateri juga memotivasi kepada para peserta pelatihan agar terus belajar dan meningkatkan kompetensi baik secara individu maupun kelompok. Hal itu dilakukan dengan harapan agar pihak desa, khususnya aparatur desa yang terlibat pada bidang keamanan dapat memanfaatkan modul pelatihan tersebut dalam proses pembimbingan dan pembekalan aplikasi Linmas bagi anggota Linmas.

\section{SIMPULAN}

Pelaksanaan Kegiatan Program Pengembangan Desa Mitra e-Desa Rimba Makmur Kecamatan Tapung Hulu Kabupaten Kampar Provinsi Riau telah dilaksanakan dengan beberapa tahapan kegiatan, dimulai dari kunjungan pendahuluan kepada masing-masing kelompok sasaran, menyepakati masalah dan solusi yang akan diterapkan, merangkai perangkat keras dan perangkat lunak, melakukan pelatihan, implementasi, dan pendampingan. Secara umum dapat disimpulkan bahwa:

1. Antusias masyarakat dalam mengikuti tahapan kegiatan pada pelatihan penggunaan aplikasi yang diterapkan pada mitra Linmas di Desa Rimba Makmur.

2. Terjadi peningkatan pengetahuan dan ketrampilan mitra dalam tata kelola berbasis teknologi informasi maupun dalam penggunakan teknologi Linmas.

Dalam akses internet sudah tersedia signal GSM pada tingkat $3 \mathrm{G}$, sudah cukup mumpuni untuk mengakses layanan di Linmas.

\section{UCAPAN TERIMAKASIH}

Terimakasih kepada Kementerian Riset dan Teknologi /Badan Riset dan Inovasi Nasional telah mendanai penelitian ini. Lembaga Penelitian dan Pengabdian STMIK Amik Riau, STMIK Amik Riau yang telah melakukan pemantauan, mengingatkan dan selalu berdiskusi tentant keberjanjutan pelaksanaan PPDM.

\section{DAFTAR PUSTAKA}

[1] M. R. Hidayat, C. Christiono, and B. S. Sapudin, "Perancangan Sistem Keamanan Rumah Berbasis Iot Dengan Nodemcu Esp8266 Menggunakan Sensor Pir Hc-Sr501 Dan Sensor Smoke Detector," Kilat, vol. 7, no. 2, pp. 139-148, 2018, doi: 10.33322/kilat.v7i2.357.

[2] S. Sukaramai, L. In, and T. Bangun, "Society Participation on Neighborhood Security System in Griya," vol. 5, pp. 1-12.

[3] M. N. Ichsan, Rancang Bangun Sistem Pendeteksi Pencurian Ternak Sapi Berbasis Mikrokontroler (Studi Kasus di Kecamatan Bontonompo Kabupaten Gowa). 2019. 
[4] F. T. Sakti and G. Pribadi, "Evaluasi Kebijakan Standar Pelayanan Minimal Pelayanan Dasar Pemeliharaan Ketertiban Umum, Ketentraman Masyarakat dan Perlindungan Masyarakat di Provinsi DKI Jakarta," J. Kelola J. Ilmu Sos., vol. 1, no. 2, pp. 98-116, 2018, doi: 10.15575/jk.v1i2.3779.

[5] Tatriwarsi, "Analisis Faktor Faktor yang Mempengaruhi Peran Serta masyarakat Kelurahan Tahunan Dalam Tugas Kamtibmas Polri Di Wilayah Polsek Umbulharjo Yogyakarta," J. Eca Cida, vol. 2, no. 1, pp. 30-51, 2018.

[6] F. Mu, E. Mardiansyah, and M. A. Nawawi, "Pendampingan Masyarakat dalam Mewujudkan Keamaan Melalui Program Siskamling Pada Komunitas Peratin Pekon Sukanegara Kabupaten Pesisir Barat Provinsi Lampung," vol. 1, pp. 61-66, 2021. 